\title{
School Meals and Milk in England and Wales, $1906-45$
}

\author{
JOHN WELSHMAN*
}

\begin{abstract}
Introduction
The recent publication of a new history of the School Medical Service, the first to appear since 1959, offers a chance to pause and reflect on the strengths and weaknesses of current work on public health in twentieth-century Britain. ${ }^{1}$ In the interwar period, the issue of nutrition served as a crucible for debates about poverty, health and welfare, and it has also been a particularly popular area for historical study. The 1906 Education (Provision of Meals) Act used to be seen as a precursor to the legislation of the 1940s, but, more recently, historians have moved on to consider the effectiveness of school meals in the depressed areas, battles over methods of assessing nutrition, the internal machinery of the Board of Education and Ministry of Health, and the links between scientific research and policy-making. Moreover, in addition to traditional empirical studies using forgotten archival material, historians have increasingly begun to employ new methodological approaches using quantitative data relating to height and weight. While this work has provided a much more sophisticated account of aspects of nutrition, the different strands of the story have not been integrated. This article, based on a narrative account that uses archival material and synthesizes recent work, seeks to re-examine the provision of school meals and milk in England and Wales from the Education (Provision of Meals) Act of 1906 to the end of the Second World War. It reassesses the impact of the early legislation, traces the slow expansion of school meals and milk in the interwar period, considers to what extent the Second World War marked a watershed, and points to local studies as one way of resolving existing problems and provoking new questions.
\end{abstract}

*Dr John Welshman, Wellcome Unit for the History of Medicine, 45-47 Banbury Road, Oxford OX2 6PE.

I would like to thank the Economic and Social Research Council for funding my research on the School Medical Service; Bernard Harris, Margaret Pelling and John Macnicol; and Medical History's editors and anonymous referees. I need hardly say that while they have all helped to improve this article, its remaining weaknesses remain my own responsibility.

\footnotetext{
${ }^{1}$ B Harris, The health of the schoolchild: a history of the school medical service in England and Wales, Buckingham, Open University Press, 1995; $\mathrm{S}$ and V Leff, The school health service, London, $\mathrm{H} \mathrm{K}$ Lewis, 1959. Earlier theses included J D Hirst, 'The origins and development of the school medical service 1870-1919', PhD thesis, University of Wales, 1983; B Harris, 'Medical inspection and the nutrition of schoolchildren in Britain, 1900-1950', $\mathrm{PhD}$ thesis, University of London, 1988; J Welshman, 'The school medical service in England and Wales, 1907-1939', DPhil thesis, University of Oxford, 1988.
} 


\section{School Meals and Milk in England and Wales, 1906-45}

\section{The Background to the 1906 Act}

In the late nineteenth century, school meals were regarded as an unnecessary intrusion on the responsibilities of parents; one commentator wrote in 1885 that "with the weakening of the spring of responsibility we could not hope for an elevation of the standard of self-respect". ${ }^{2}$ Nevertheless, in the larger cities voluntary organizations provided meals for children deemed "necessitous", and the debate about physical deterioration also raised questions about how many children were malnourished and whether this was due to poverty or ignorance. The author Arnold White criticized the popularity of tinned fish and frozen meat, while Major-General Sir Frederick Maurice was only one of a number of observers who were critical of the cooking abilities of workingclass mothers. ${ }^{3}$ Several Government committees also considered nutrition. The 1903 Report of the Royal Commission on Physical Training in Scotland tried to estimate how many children in Aberdeen and Edinburgh were malnourished, and noted that meals might have to be provided in schools if physical training was expanded. While the Commission was anxious not to interfere with the independence of parents, it recommended that School Boards should monitor the nutritional state of children, offer facilities so that voluntary organizations could provide meals, and offer lunches themselves, to be paid for by parents, if the work of charities was inadequate. ${ }^{4}$

Some witnesses appearing before the Inter-Departmental Committee on Physical Deterioration repeated the familiar claims that lazy housewives relied on tinned food and fish and chips, but others, including Dr Eichholz, the Board's inspector, found that, in London, children were malnourished and charities provided limited assistance. In its report, published in 1904, the Committee recommended that voluntary organizations should continue to have the primary responsibility for providing school meals, and that local authorities should step in only when they were unable to cope. ${ }^{5}$ Others were similarly conservative; a contributor to a book by E J Urwick, Sub-Warden of Toynbee Hall, found that children lived on fried fish and tinned meat and cheese, and claimed that "an improper rather than an inadequate diet is the evil that demands a remedy", while Samuel Barnett, Warden of Toynbee Hall, warned that the introduction of free school meals would erode the function of meals in strengthening family values. ${ }^{6}$ The 1905 InterDepartmental Committee on Medical Inspection and Feeding considered services for schoolchildren in France and Germany, but while it suggested that Local Education Authorities (LEAs) should use School Medical Officers (SMOs) and nurses rather than head teachers to assess nutrition, it was nervous that school meals would destroy family life. Confident in the capacity of voluntary organizations, it concluded that the real solution lay in the education of working-class mothers. ${ }^{7}$

2 S D Fuller, 'Penny dinners', Contemp. Rev., 1885, 48: 424-32, p. 428.

3 A $\mathrm{H}$ White, Efficiency and empire, London, Methuen, 1901, p. 104; F Maurice [Miles], 'Where to get men', Contemp. Rev., 1902, 81: 78-86, p. 85.

${ }_{4}$ PP 1903, XXX (Cd. 1507, 1508), Report of the Royal Commission on Physical Training (Scotland), vol. 1, pp. 24, 29-31, 37.

5 PP 1904, XXXII (Cd. 2175, 2186, 2210), Report of the Inter-Departmental Committee on
Physical Deterioration, vol. 1, pp. 40-2, 67-9, 91.

6 E J Urwick, Studies of boy life in our cities, London, J M Dent, 1904, p. 52; S A Barnett, 'Public feeding of children', Independent Rev., 1905, 6: 154-62, passim.

7 PP 1906, XLVII (Cd. 2779, 2784), Report of the Inter-Departmental Committee on Medical Inspection and Feeding of Children attending Public Elementary Schools, vol. 1, pp. 63, 68-70, 84. 


\section{John Welshman}

These debates indicated the strength of conservative interpretations of poverty and family life, and many of these assumptions were shared by civil servants at the Board of Education. In February 1906, E H Pelham, Private Secretary to the Parliamentary Secretary, admitted that voluntary organizations worked independently of each other, but argued that poor housing, overcrowding, inadequate clothing and inferior maternal care were more significant causes of ill-health among children than malnourishment. ${ }^{8}$ Nevertheless, interest in school meals had increased, and in the same month the Education (Provision of Meals) Bill of 1906, a private member's bill sponsored by F W Jowett, Labour MP for Bradford West, sought to amend the Education Acts of 1902 and 1903, stating that LEAs could provide meals for children who "are unable by reason of lack of food to take full advantage of the education provided for them". 9 At second reading, Jowett observed that Bradford provided school meals since certain trades were characterized by low wages and charities had limited resources, and the Bill was sent to a Select Committee. This noted that some local authorities like Bradford and London had set up ambitious school meals programmes, and recommended that LEAs could aid "school canteen committees", but limited rate-funded expenditure on meals to a half penny in the pound, urged LEAs to encourage charities, and emphasized that they should recover costs from parents and prosecute them in cases of neglect. ${ }^{10}$ In society generally, there was a vigorous debate on school meals between those who favoured state intervention, and others who maintained that malnutrition was a problem of poor parental care, and who opposed school meals funded out of the rates. ${ }^{11}$ However, following some minor House of Lords amendments, the 1906 Education (Provision of Meals) Act received Royal Assent on 21 December. ${ }^{12}$ Between 1899 and 1906, fears of physical deterioration focused attention on general issues surrounding child health, but the tone of these debates was conservative, and the example of Bradford and the efforts by Jowett played a more significant role in determining the form and outcome of the 1906 legislation.

8 Public Record Office, Kew, London (hereafter PRO) ED 24/107, E H Pelham to A Birrell, 26/2/06.

${ }^{9}$ PP 1906, I, p. 1109.

10 PP 1906, VIII, Special Report from the Select Committee on the Education (Provision of Meals) Bill, pp. ix-x, 43, 51-4, 62-3; PP 1906, I, pp. 1113-16.

$11 \mathrm{~K}$ Herbert, 'The teaching of cookery', Nineteenth Century and After, 1906, 351: 811-24; F E Greville, A nation's youth: physical deterioration, its causes and some remedies, London, Cassell, 1906, p. 28; J E Gorst, The children of the nation: how their health and vigour should be promoted by the state, London, Methuen, 1906, p. 76; W R Anson,

'Provision of food for school-children in public elementary schools', Econ. J., 1906, 62: 181-8.

12 PP 1906, I, pp. 1121-2; PRO ED 24/107, details of passage of Act. Many of the older accounts were written by historians of education; see also G A N Lowndes, Margaret McMillan, 'the children's champion', London, Museum Press, 1960, pp. 95-6; $\mathrm{M}$ Bruce, The coming of the welfare state, London, B T Batsford, 1961, 2nd edn, 1965, pp. 192-3; B Simon, Education and the Labour movement,
1870-1920, London, Lawrence and Wishart, 1965 , pp. 279-85; B B Gilbert, The evolution of national insurance in Great Britain: the origins of the Welfare State, London, Michael Joseph, 1966, pp.' 100-2; R J W Selleck, The new education, 1870-1914, London, Pitman, 1968, pp. 167-74; D J Oddy, 'A nutritional analysis of historical evidence: the working class diet, 1880-1914' in D J Oddy and D S Miller (eds), The making of the modern British diet, London, Croom Helm, 1976, pp. 214-31; J Brown, 'Social control and the modernisation of social policy, 1890-1929', in P Thane (ed.), The origins of British social policy, London, Croom Helm, 1978, pp. 133-5; J S Hurt, Elementary schooling and the working classes 1860-1918, London, Routledge and Kegan Paul, 1979, pp. 105-28. More recent accounts include J Macnicol, The movement for family allowances, 1918-45: a study in social policy development, London, Heinemann, 1980, pp. 7, 44-5; K Laybourn, 'The issue of school feeding in Bradford 1904-1907', J Educ. Adm. Hist., 1982, 14(2): 30-8; P Thane, The foundations of the Welfare State, London, Longman, 1982, pp. 75-6; Harris, op. cit., note 1 above, pp. 6-47, 77 . 


\section{Limited Progress, 1906-18}

The Board of Education's circular of January 1907 noted that the Act's aim was "to ensure that children attending public elementary schools shall, so far as possible, be no longer prevented by insufficiency of suitable food from profiting by the education offered in our schools". It emphasized that the Act was permissive and imposed no duties on LEAs who thought it unnecessary. ${ }^{13}$ LEAs in cities where the Independent Labour Party was strong, such as Bradford, quickly took up the new powers provided through the legislation and extended existing meals schemes, so that in 1910 the city served a total of 957,739 meals. ${ }^{14}$ Yet while some local authorities quickly made progress, others did not adopt school meals, and they received little real guidance from the annual reports of the Board's Chief Medical Officer (CMO) Dr George Newman. Newman had been a bacteriologist and MOH for Finsbury and Bedfordshire, and in 1906 he had published an important study of infant mortality, but his background meant that he took a conservative approach to child health. On nutrition, for example, he told SMOs that at medical inspections they should classify the nutrition of schoolchildren as "good (meaning excellent)", "normal", "below normal", and "bad". ${ }^{15}$ While he quickly realized that cursory medical inspections produced figures with improbable regional variations, he persisted with this method and hoped that the superficially impressive statistics on the expansion of school meals would distract attention from its obvious flaws. In 1912, for example, Newman conceded that it was difficult to assess nutrition, and he noted that the number of children classed as "subnormal" or "bad" varied from 2.2 per cent in Anglesey to $\mathbf{1 8 . 6}$ per cent in Dorset in the counties, and in the urban areas from 0.8 per cent in Walthamstow to 31.4 per cent in West Hartlepool. Newman admitted that the statistics could not be used for regional comparisons, and any conclusions were tentative as "it cannot be said that any completely satisfactory index has yet been found", but he argued that figures would become standardized as SMOs became more experienced. ${ }^{16}$ Apart from the problems in assessing malnutrition, reports also emphasized that LEAs should encourage parents to spend rationally, and should use the school meal as an opportunity to inculcate good manners. ${ }^{17}$ The Board warned LEAs that if they regarded meals as a cheap form of poor relief, any results would be insignificant and short-lived, but in 1913 the Medical Officer stated that "nearly all authorities provide the meals with great reluctance and look upon them as a species of outdoor-relief which has been thrust upon them". ${ }^{18}$ Even in this early period, the Board of Education doubted the accuracy of

13 PRO ED 24/108, Board of Education, circular $552,1 / 1 / 07$.

14 R H Crowley and M E Cuff, Report on a course of meals given to necessitous children from April to July 1907, Bradford Education Committee, 1907, pp. 3, 11-12; Bradford Education Committee, Report of the SMO, 1907, Bradford Education Committee, 1908, pp. 13-14; E R Hartley, How to feed the children: Bradford's example!, Bradford, H Beaumont, 1908, pp. 11-12; J H Palin, 'The feeding of school children, Bradford's experience', Socialist Rev., 1908, 1: 207-19, p. 214; Bradford Education Committee, Extracts from SMO Reports, Bradford Education Committee, 1910, p. 36.
15 PP 1910, XXIII (Cd. 4986), Annual report of the CMO, 1908, pp. 10, 44.

16 PP 1914, XXV (Cd. 7184), Annual report of the CMO, 1912, pp. 27-8, 271.

17 PP 1911, XVII (Cd. 5925), Annual report of the CMO, 1910, pp. 26, 31; PP 1910, XXIII (Cd. 5131), Report on the working of the Education (Provision of Meals) Act, 1906 up to the 31st March 1909 , p. 5.

${ }_{18}$ Med. Offr, 1913, 9: 2. On the development of treatment see J D Hirst, 'The growth of treatment through the school medical service, 1908-18', Med. Hist., 1989, 33: 318-42. 


\section{John Welshman}

assessing malnutrition through medical inspections, and was determined that school meals should not become a welfare benefit.

While some were over-optimistic about meals or blamed working-class mothers for bad housekeeping, others argued that the State should assume responsibility and expand school meals. ${ }^{19}$ New surveys of family budgets also revealed much about the place of food in working-class households. In the study by the Fabian Women's Group of the budgets of working-class families in Lambeth, Maud Pember Reeves found that there was little variety in diets, bread was the main food, and the lack of storage space forced housewives to spend more money shopping each day. She suggested that mothers could only cook more efficiently with more time and better utensils, and while she accepted that diets were poor, she denied that the ignorance and indifference of housewives were responsible. ${ }^{20} \mathrm{In}$ a pamphlet on school meals published in a series on social policy sponsored by the University of Birmingham, Phyllis Winder agreed from a survey of 200 families receiving free meals that malnutrition among children would be solved only with education, better housing, improved welfare benefits, and full employment. ${ }^{21}$ The history of school meals published in 1914 by Mildred Bulkley, Secretary of the Ratan Tata Foundation, an organization directed by $\mathrm{R} \mathrm{H}$ Tawney under the auspices of the London School of Economics to promote the study of methods of preventing poverty, found that the selection of children and provision of meals varied between LEAs. Many were inefficient, and many children were overlooked; there was little attempt to link meals with the rest of the School Medical Service; meals were not provided during school holidays; and they were particularly poor in rural areas. While Bulkley believed that industry should solve the problem of low wages, she recommended that LEAs should provide meals for all children, SMOs should advise on menus, meals should be educational, and they should be continued throughout the year and during the holidays. ${ }^{22}$

These points about the weaknesses of school meals, and the wider debate about poverty, were embodied in efforts to extend the 1906 legislation. In 1913, Newman noted that few LEAs in rural areas had adopted the legislation, and in the following year the Education (Provision of Meals) Bill, initiated by F W Jowett, attempted to amend the 1906 Act. $^{23}$ The Bill proposed to remove the halfpenny in the pound limit on expenditure from the rates, to legalize the provision of meals during the holidays, and to compel LEAs to provide meals for the children found at medical inspections to be malnourished. The Bill stated that SMOs rather than LEAs were to decide whether a child was underfed, thus emphasizing that meals were primarily provided for educational reasons rather than as a form of poor relief, but even so the Charity Organisation Society complained that it would

19 M McMillan and A Cobden-Sanderson, London's children, how to feed them and how not to feed them, London, 1909, pp. 2-3; J Kerr and E W Wallis, Transactions of the Second International Congress on School Hygiene, London, Royal Sanitary Institute, 1908, p. 79.

20 L S Bryant, School feeding: its history and practice at home and abroad, London, J B Lippincott, 1913, p. 76; C E Hecht (ed.), Rearing an imperial race, London, St Catherine Press, 1913, p. 108; M Pember Reeves, Round about a pound a week, London, G Bell and Sons, 1913, Virago edn, 1979, pp. 97, 103, 131, 145.

21 P D Winder, The public feeding of elementary school children, London, Longmans, 1913, pp. 47, 76.

22 M E Bulkley, The feeding of school children, London, G Bell and Sons, 1914, pp. xv, 75, 127-9, 201, 228-9.

23 PP 1914-16, XVIII (Cd. 7730), Annual report of the CMO, 1913, p. 244. 
wreck the work of its Children's Care Committees. ${ }^{24}$ The Education (Provision of Meals) Act of 1914 strengthened the 1906 Act; LEAs could now obtain grants to cover 50 per cent of their expenditure on meals, and Newman argued that "potentially in each educational area the machinery now exists for feeding all the school children if necessary". 25

However, despite the new legislation, education remained the focus for much of Newman's advice to LEAs. He wrote that only "persistent, kindly, and skilled missionary effort" would persuade people to change their eating habits, and he suggested that LEAs and local authority public health services should promote health education and encourage parents to make their homes "suitable training grounds for children of good nutrition and sound physique". ${ }^{26}$ During the First World War, Newman attempted to explain annual increases and decreases in the provision of meals by relating them to changes in the level of wages, food prices and employment patterns. ${ }^{27}$ The Board's own statistics indicate that between 1914-15 and 1918-19, the number of LEAs providing meals fell from 134 to 86, the number of children fed fell from 422,401 to 53,742 , and the total number of meals supplied fell from 29 million to 5 million, while the average total cost per meal rose from 2.47 to $5.98 \mathrm{~d}^{28}$ Clearly fewer children received school meals during the War, but whether this was due to reduced demand owing to better employment opportunities and higher wages, or in response to cuts made by local authorities, is not clear. Some SMOs reported that children were better fed and clothed, but the evidence of medical inspections is notoriously unreliable, and the staff of the School Medical Service had also been depleted by wartime conditions. It is debatable whether reductions in the number of school meals served necessarily indicated rises in living standards, and historians have tried to relate the health of schoolchildren to wider economic and social conditions in London only, so that the impact of the War on child health in other parts of England and Wales is not known. Overall it would appear that the First World War had little impact on existing levels of child health. ${ }^{29}$

\section{Retrenchment and Rationing, 1919-29}

After the First World War there was a brief period of expansion, so that in 1919-20 there were slight increases in the number of LEAs providing meals, the number of children fed, and the total number of meals supplied. ${ }^{30}$ However, the financial

24 PP 1914, II, pp. 57-62; PRO ED 24/621, 'Education (Provision of Meals) Bill, 1914', p. 1; ibid., J C Pringle to C Nicholson, 31/7/14.

${ }_{25}$ PP 1914-16, XVIII (Cd. 7730), Annual report of the CMO, 1913, p. 256.

26 PP 1914-16, XVIII (Cd. 8055), Annual report of the CMO, 1914, pp. 75, 201, 221-2.

27 Ibid., p. 202; PP 1916, VIII (Cd. 8338), Annual report of the CMO, 1915, p. 87; PP 1917-18, XI (Cd. 8746), Annual report of the CMO, 1916, p. 142; PP 1918, IX (Cd. 9206), Annual report of the CMO, 1917, pp. 128-9, 135; PP 1919, XXI (Cmd. 420), Annual report of the CMO, 1918, p. 174.

${ }^{28}$ Harris, op. cit., note 1 above, p. 78, table 5.6.
29 See also J Winter, The Great War and the British people, London, Macmillan, 1986, pp. 240-5; L Bryder, 'The First World War: healthy or hungry?', Hist. Workshop J., 1987, 24: 141-57; R Wall, 'English and German families and the First World War 1914-18', in R Wall and J Winter (eds), The upheaval of war: family, work and welfare in Europe 1914-18, Cambridge University Press, 1988, pp. 43-106; B Harris, 'The demographic impact of the First World War: an anthropometric perspective', Soc. Hist. Med., 1993, 6(3): 343-66; idem, op. cit., note 1 above, pp. 83-5.

30 Harris, op. cit., note 1 above, p. 78, table 5.6. 


\section{John Welshman}

retrenchment of the early 1920 s hit the provision of school meals, and the Board adopted a rationing system. In his report for 1920, Newman warned LEAs to be careful that the school meals system was not abused, while the Board's circular of June 1921 noted that expenditure on school meals could escalate during economic depressions. ${ }^{31}$ During the 1921 coal strike, over 60 million meals were served at a cost of almost $£ 1$ million, and the Board felt that this expenditure was on a scale greater than had been anticipated by the 1906 Act. The Board's estimates for expenditure in 1922-23 were $£ 3.75$ million, whereas the Geddes Committee had recommended a limit of $£ 3$ million, and in January 1922 , H A L Fisher, the Board's President, reluctantly agreed to limit expenditure on the School Medical Service. On 4 April, Fisher told the House of Commons that "the financial and administrative burden which has been thrown on the system of education is much greater than it can or ought to carry", and that expenditure on meals in 1922-23 would be limited to $£ 300,000$. $^{32}$

The Board's circular of May 1922 told LEAs to reorganize school meals schemes, and Directors of Education in areas such as Mountain Ash in South Wales protested that grants towards school meals would be inadequate during a future coal strike. ${ }^{33}$ The Board set up a rationing system by comparing the provision of meals and expenditure in each year since 1906 with the unemployment figures, and in August it informed LEAs that it would allocate $£ 250,000$ for school meals. There were protests from about 50 LEAs between August and December, and their revised estimates for $1923-24$ came to $£ 338,283 .{ }^{34}$ In December, the Treasury reluctantly agreed to increase expenditure to $£ 335,000$, noting that with unemployment, expenditure on these services became more difficult to control. ${ }^{35}$ The Board's Permanent Secretary, Sir Lewis Selby-Bigge, pointed out to Fisher that the LEAs' estimates indicated that those hardest hit by unemployment were spending least, but in January 1923 the Board sanctioned expenditure of $£ 310,000$, having reduced the estimates of 16 LEAs. ${ }^{36}$ Newman maintained that school feeding in 1921-22 had been excessive and unnecessary, and the economic depression and the reduction in the number of meals due to the rationing system had not affected the health of schoolchildren. ${ }^{37}$

In 1918-21, Edward Mellanby, Professor of Physiology in London until he went to Sheffield in 1920, had identified rickets as a deficiency of fat-soluble vitamin D, but while nutritional science in the interwar period was dominated by research into vitamins, it was the Medical Research Council (MRC) surveys which had a more significant impact on social policy. Despite Mellanby's work, one of the main areas of debate at the beginning

31 PP 1921, XI (Cmd. 1522), Annual report of the CMO, 1920, pp. 147-8, table 1 .

32 MS, H A L Fisher, Bodleian library, Oxford: 64-147, 'LEAs expenditure 1922-23', 12/21; ibid., 64-161, p. 15; ibid., 64-153, 'Cabinet Committee. Note by the President of the Board of Education', 9/1/22; ibid., 64-176, 'Geddes Report-Note upon Treasury memorandum of 20 Jany 1922', p. 9; PRO ED 24/1372, 'Historical note, 1906-1923', 26/1/23, pp. 2-3. See also C Webster, 'Health, welfare and unemployment during the Depression', Past and Present, 1985, 109: 204-30.

33 PRO ED 24/1373, A Morgan to H A L Fisher, 4/5/22; Board of Education, Health of the school child: annual report of the Chief Medical Officer for 1921, London, HMSO, 1922, p. 41.

34 PRO ED 24/1372, 'Historical note, 1906-1923', 26/1/23, p. 5.

35 PRO ED 24/1373, L A Selby-Bigge to G Barstow, 14/12/22; ibid., G Barstow to Leeson, 14/12/22; ibid., G Barstow to L A Selby-Bigge, $15 / 12 / 22$.

36 Ibid., L A Selby-Bigge to H A L Fisher, 28/12/22; PRO ED 24/1372, 'Historical note, 1906-1923', 26/1/23, p. 5.

37 Health of the school child, 1922, London, HMSO, 1923, pp. 10, 122-4. 
of the decade was over the causes of rickets. Noel Paton, Professor of Physiology at Glasgow, and his colleagues Leonard Findlay and Margaret Ferguson maintained that rickets was not due to dietary deficiencies, but to poor housing, lack of fresh air, and improper care by parents. Frederick Gowland Hopkins, Professor of Biochemistry at Cambridge, sided with Mellanby, and an MRC survey published in 1922 argued that poor housing, overcrowding, and lack of ventilation were not responsible for rickets, most cases were linked to poverty, and measures to reduce casual labour or improve diets would reduce the incidence. ${ }^{38}$ The debate on rickets influenced some SMOs. In 1925, Dr G C M M'Gonigle, SMO for Stockton-on-Tees, claimed that his investigation of 2,676 children in Durham indicated that 83 per cent definitely had rickets, 11 per cent had slight but definite signs of rickets, and only 6 per cent did not have rickets. In a further article published in 1927, M'Gonigle noted that varying standards among SMOs meant that much of their work on diseases such as rickets was useless. ${ }^{39}$ At the MRC, Major Greenwood, Professor of Epidemiology and Vital Statistics at the London School of Hygiene and Tropical Medicine, stressed that each child in the proposed MRC survey should have two examinations, and he subsequently agreed that the Board's statistics on rickets were "quite valueless". 40

The issue of rickets highlighted important differences between chemical physiologists and biochemists, but it was in later MRC reports that the influence of the "Glasgow school" was more obvious. In 1924, E P Cathcart, Professor of Physiological Chemistry at Glasgow University, claimed that his survey of mining districts demonstrated that factors other than diet influenced the nutrition of children, and that families where the mother had been in domestic service had a better diet than average. ${ }^{41}$ Cathcart's conclusion, that education on diets could help housewives to buy food more efficiently, was echoed by the survey of urban and rural districts of Scotland published by Noel Paton and Leonard Findlay in 1926. Paton and Findlay acknowledged the importance of housing, but they classified mothers as "good", "bad", and "indifferent", and they argued that the most important factor in improving living conditions and children's health was not family income, but maternal care and the efficiency of the mother. ${ }^{42}$

In the early 1930s, the MRC's Special Report Series included two other studies by E P Cathcart and A M T Murray. In a survey of 154 families in St Andrews, they claimed that there was no correlation between increases in children's heights and the amount of money spent on food, and they suggested that the children of the unemployed were below average height for hereditary rather than nutritional reasons; they concluded that "the welfare and

38 L Findlay and M Ferguson, A study of social and economic factors in the causation of rickets, London, MRC, 1918, special report series 20, pp. 98-9; MRC Archive, London, 99, correspondence from N Paton and L Findlay, and F Gowland Hopkins, 12/8/18-15/11/21; H CorryMann, Rickets: the relative importance of environment and diet as factors in causation: an investigation in London, London, MRC, 1922, special report series 68 , pp. 79-80, 83. (Although I have retained the original file numbers, the MRC archive has been moved to Kew and can be found in the PRO FD series.)
39 G C M M'Gonigle, 'Rickets and tonsils and adenoids', Med. Offr, 1925, 34: 5-8; idem., 'The geographical distribution of defects among school children', Med. Offr, 1927, 36: 27.

40 MRC archive 1452, M Greenwood to A F Landsborough Thomson, 23/11/27 and 8/12/27.

41 E P Cathcart, Report on the nutrition of miners and their families, London, MRC, 1924, special report series 87 , pp. 21, 46-7.

$42 \mathrm{~N}$ Paton and L Findlay, Poverty, nutrition and growth: studies of child life in cities and rural districts of Scotland, London, MRC, 1926, special report series 101 , pp. 227, 300-2, 304-5. 
physical condition of the children is a function of the parental efficiency". ${ }^{43}$ In a survey of family diets in Cardiff and Reading, Cathcart and Murray claimed that they had found little evidence of malnutrition in the children of poor families, and although they admitted that people living on higher incomes ate more fat, they argued that "improvidence" or "general incapacity" was still more important than low incomes. ${ }^{44}$ It is not clear how far these studies influenced Newman but he was similarly conservative, writing in his annual report for 1926 that "more often it is careless mothering, ignorance of upbringing and lack of nurture than actual shortage of food which results in a malnourished child" ${ }^{45}$ The eugenic emphasis on "parental inefficiency" was in line with Government passivity on welfare, and was challenged effectively by pressure groups only in the late 1930s.

While research sponsored by the MRC had an important impact on policy, the Board continued to struggle with the issue of school meals during strikes and economic slumps. In February 1924, Charles Trevelyan, the new President of the Board, abolished the rationing system imposed during the coal strikes of 1921-22 after the estimates for 1923-24 fell within the $£ 300,000$ limit. Yet Newman maintained that school meals had become an extravagant form of relief, and the Board tightened up the administration of meals schemes by approving only those which included low income scales and arrangements with the Boards of Guardians for the feeding of "relief" cases. ${ }^{46}$ In July 1925, the Board's Assistant Secretary concluded from his review of the rationing system that while the Board could refuse to sanction the expenditure of an LEA which provided meals for the children of strikers, there would be serious trouble if there was a strike in a mining area and no meals were provided. However, during the 1926 coal strike the Board's new system worked effectively; LEAs were forced to select fewer children for meals, and after the provision of meals peaked in May, means tests enabled them to reduce the number of children receiving free meals. Newman claimed that there was less malnutrition and the 1926 coal strike had not affected the health of schoolchildren; indeed the country should congratulate itself that "the duty was discharged so effectively and economically". 47 The result was that only half as many meals had been served in 1926 as in 1921.

43 E P Cathcart and A M T Murray, A study in nutrition: an inquiry into the diet of 154 families of St Andrews, London, MRC, 1931, special report series 151, pp. 49-51.

${ }^{44}$ Idem, Studies in nutrition: an inquiry into the diet of families in Cardiff and Reading, London, MRC, 1932, special report series 165, pp. 9, 18, 28.

${ }^{45}$ Health of the school child, 1926, London, HMSO, 1927, p. 16. See also G Jones, 'Eugenics and social policy between the wars', Hist. J., 1982, 25: 717-28, pp. 720-1; idem, Social hygiene in twentieth century Britain, London, Croom Helm, 1986, pp. 73-81, 129; D Smith and M Nicolson, 'The "Glasgow school" of Paton, Findlay and Cathcart: conservative thought in chemical physiology, nutrition and public health', Soc. Stud. Sci., 1989, 19: 195-237; C Petty, 'Primary research and public health: the prioritization of nutrition research in inter-war Britain', in J Austoker and L Bryder (eds),
Historical perspectives on the role of the MRC: essays in the history of the Medical Research Council of the United Kingdom and its predecessor, the Medical Research Committee, 1913-1953, Oxford University Press, 1989, pp. 83-108.

46 PRO ED 50/77, G Newman to L A SelbyBigge, 29/1/24, pp. 3-4; PRO T161/227/S23263, C Trevelyan to P Snowden, 1/2/24; ibid., C Trevelyan, 'Note of discussion with the Chancellor of the Exchequer on 8th February 1924', 9/2/24; PRO ED 24/1372, 'Note by Mr A H Wood on the provision of meals by Local Education Authorities in times of special industrial disturbance', 20/7/25, p. 5.

47 PRO ED 24/1372, 'Note by Mr A H Wood on the provision of meals by Local Education Authorities in times of special industrial disturbance', 20/7/25, pp. 8-9; Health of the school child, 1926, London, HMSO, 1927, pp. 10-11, 137-9. 


\section{School Meals and Milk in England and Wales, 1906-45}

Newman's report for 1927 noted that the problems of the coal industry constituted "profound economic changes which no medical service, no school feeding and no poor relief, however extensive, can alter or remedy", and conditions in the North East of England and South Wales remained extremely serious. ${ }^{48}$ A survey of South Wales by the Board's inspectors completed in February 1928 found that no school meals had been served in Pontypridd, Merthyr Tydfil, Mountain Ash, Ebbw Vale and Glamorgan in 1927, and that meals had been served only irregularly in Abertillery. The inspectors concluded that the situation could deteriorate at any time. They claimed that the depression had not affected the health of schoolchildren, but found that adequate nutrition had been maintained only by the extension of meals during the coal strike, and recommended that these LEAs could continue to provide meals. ${ }^{49} \mathrm{~A}$ Labour Party report agreed that in many cases mothers giving up food for their children was what had prevented malnutrition, which would increase if the economic depression continued ${ }^{50}$ In 1929, attention switched to the North East of England. The previous year, the Board's inspector had found that Durham was providing no school meals although 7.5 per cent of children were malnourished, and in April 1929 the Board's investigators found that the health of Durham schoolchildren had worsened. Only a few of the malnourished children in Hebburn got meals, and in Northumberland as a whole the health of children had been maintained only by the sacrifices of their parents. ${ }^{51}$

Lord Eustace Percy, the Board's President, wrote that the report on South Wales had been drafted quickly and predictions exaggerated; he did not send it to the LEAs but treated it as confidential and informal. ${ }^{52}$ Yet while Newman maintained that the health of schoolchildren was unaffected by the industrial depression, he agreed that parents had nothing to fall back on and their children would suffer unless they got help from other sources. ${ }^{53}$ The Board was now forced to consider how far it provided school meals for education, and to what extent it was responsible for the relief of poverty. It was aware that parents were reluctant to apply for school meals because they were included in assessments for poor relief, but its circular of April 1928 limited provision to the terms of the 1906 Act, stating that LEAs should not provide meals for children whose parents were receiving relief from the Boards of Guardians. The Board now encouraged LEAs to select children for school meals through medical inspections rather than income scales, and Newman's report for 1929 maintained that as a result of the efforts of the Coalfields Distress Fund and other voluntary organizations, LEAs had "more or less held in check any rapid deterioration in the physique of school children". ${ }^{44}$ At the same time in

48 Health of the school child, 1927, London, HMSO, 1928, p. 110.

49 PRO ED 50/83, A Eichholz, J E Underwood and A F Birch-Jones, 'South Wales coal mining areas: investigation into the physique of school children', 11/1/28, pp. 28-30, 33, 53-4; ibid., J E Underwood, 'General conclusions', p. 1.

${ }_{50}$ PRO MH 55/691, R J Davies, F W Pethick Lawrence and H Evans, 'The distress in Wales', 8/3/28, p. 11.

${ }^{51}$ PRO ED 50/77, A Eichholz, 'Durham coal mining areas: investigation into the physique of school children', $4 / 28$, p. 42 ; ibid., reports on Durham, Northumberland, Hebburn, Sunderland, and Newcastle, 1-6/2/29.
52 PRO MH 55/280, E Percy to N Chamberlain, $16 / 1 / 28$, p. 1.

53 Ibid., G Newman to E Percy, 17/1/28, pp. 1-2.

54 PRO ED 50/83, H W Francis to Major Dixon, 27/1/28, pp. 1-2; PRO ED 50/77, W C Eaton to G Newman, 3/4/28; PRO ED 50/83, G Newman, 'Physical conditions in South Wales', 6/4/28, p. 6; Health of the school child, 1929, London, HMSO, 1930 , p. 10. See also B Harris, 'Government and charity in the distressed mining areas of England and Wales, 1928-30', in J Barry and C Jones (eds), Medicine and charity before the Welfare State, London, Routledge, 1991, pp. 207-24. 
November 1929, Percy admitted that only an end to the economic slump could solve the problem of malnutrition among schoolchildren in the depressed areas, and in his autobiography he regretted that in this period he had not overhauled the system for providing school meals so that the School Medical Service could have tackled the more serious problems which developed in the following decade. ${ }^{55}$

\section{Malnutrition and the School Milk Scheme, 1930-34}

New debates between rival committees revealed that even among scientists there was little consensus on the subject of nutrition. In 1931, the Ministry of Health, recognizing that Government departments lagged behind advances in nutritional research, set up an Advisory Committee on Nutrition. Paton had died in 1928 and Findlay was no longer involved in research, but Cathcart continued to argue that inefficiency was a more significant cause of malnutrition than poverty, while other members of the Advisory Committee, such as Mellanby and Gowland Hopkins, favoured the "Oslo" breakfasts which were served free to children in Scandinavian countries. ${ }^{56}$ In November 1933, the Advisory Committee's chairman, Major Greenwood, wrote that it was divided and ineffective, and more serious disagreements followed the formation of the rival committees on nutrition by the journal the Weekend Review and the British Medical Association (BMA) in 1933. ${ }^{57}$ The Weekend Review's committee attempted to define the minimum cost of an adequate diet for adults and children, and this was something the Advisory Committee had considered but rejected because of its obvious relationship with rates of unemployment benefit; one civil servant admitted that "in view of its wide and possibly embarrassing repercussions they thought it better to restrict themselves to general principles". ${ }^{58}$ The report of the BMA's committee was more serious since it recommended a minimum diet of 3,400 calories and $50 \mathrm{~g}$ of first class protein, whereas the Advisory Committee had suggested 3,000 calories and $37 \mathrm{~g}$ of first class protein. Some members of the Advisory Committee reacted angrily. ${ }^{59}$

In December 1933, the Advisory Committee decided that its original estimates could still be used for calculating minimum diets and levels of unemployment benefit, but the Labour Party concluded that the current scales of unemployment pay were inadequate to meet the minimum food requirements of an average family. ${ }^{60}$ In February 1934, meetings with representatives of the two committees finally produced a joint report which tried to reconcile the opposing views through a sliding scale of daily calorie requirements for men, women and children including $80-100 \mathrm{~g}$ of protein. The Ministry of Health's circular claimed that there were no fundamental disagreements between the two committees, but

55 PRO ED 50/83, E Percy to G Newman, $8 / 11 / 29$; idem, Some memories, London, Eyre and Spottiswoode, 1958, p. 118.

56 PRO MH 56/44, memorandum by E P Cathcart, $1 / 4 / 31$, pp. 2, 4; PRO MH 56/251, Advisory Committee on Nutrition, 'The Oslo breakfast'.

57 PRO MH 56/52, J Campbell to J C Wrigley, 5/5/32; PRO MH 56/40, M Greenwood to F R Hudson, 21/11/33.

58 PRO MH 56/40, cutting from the Week-End
Review, 1/4/33; ibid., T Carnwath to G Newman, 4/4/33.

59 PRO MH 56/55, M Greenwood to G Newman, 30/11/33; ibid., G Newman to Secretary, 4/12/33; PRO MH 56/48, memoranda by E P Cathcart, $8 / 12 / 33$.

60 PRO MH 56/40, 'Minutes of the sixth meeting of the Advisory Committee', 15/12/33, p. 3; PRO MH 56/55, Ministry of Health, circular 1370 , Nutrition, 4/1/34. 


\section{School Meals and Milk in England and Wales, 1906-45}

this was an unconvincing attempt to patch up serious differences, and Greenwood resigned. ${ }^{61}$ The conservative approach to nutrition and poverty popularized by the "Glasgow school" had been influential in the 1920s but steadily lost ground in the mid1930s. A new enlarged Advisory Committee was appointed in May 1935 to enquire into diet and to report any changes necessary in the light of research, and its first report took a more progressive line.

The debates about the recommendations of the two committees had implications for the Board's assessment of malnutrition and its provision of meals. In 1931, Newman had acknowledged that SMOs should use clinical examinations with height and weight measurements and blood tests, and the Board's internal enquiry in 1934 found from an examination of schoolchildren in 11 areas that the returns were inaccurate and not comparable with one another. The report's author, Dr R H Simpson, recommended that at clinical examinations SMOs should distinguish between four categories of nutrition (two "normal" and two "subnormal"), reports should make more use of percentages, and the term "malnutrition" should no longer be used. ${ }^{62}$ Simpson's report was not published, but his recommendations were embodied in the memorandum issued in December 1934. This stated that SMOs should classify the nutrition of schoolchildren in four groups, they should change the "good" category to "excellent", and "subnormal" to "slightly subnormal", and they should not base assessments on age, sex, height and weight, but on other data derived from clinical examinations. These included the "general appearance, facies, carriage, posture; the condition of the mucous membranes; the tone and functioning of the muscular system; and the amount of subcutaneous fat". The memorandum stated that an "alert cheerful child, with bright eyes and a good colour" could be considered well-nourished, while one who was "dull, listless and tired, who has a muddy complexion or stands slackly" should be examined further. ${ }^{63}$ Newman's annual report for 1934 admitted that it was difficult to define "subnormal" and "bad" nutrition accurately, but he was confident that an experienced SMO could assess nutrition "sufficiently accurately for practical purposes". ${ }^{64}$

If there was more interest in methods of assessing nutrition, the provision of meals in the depressed areas continued to attract attention. In February 1930, the Board's inspector found that in South Wales medical inspections and school meals were "just sufficient, and only

61 PRO MH 56/55, Labour Party, 'Notes for speakers: the BMA Report on nutrition', 1/2/33; PRO MH 56/40, M Greenwood to E Hilton Young, 11/2/34; PRO MH 56/56, 'Summary of proceedings of joint conference on nutrition', 6/2/34; ibid., Ministry of Health, Nutrition: report of conference between representatives of the Advisory Committee on Nutrition and representatives of a Committee appointed by the BMA, London, HMSO, 1934. See also Macnicol, op. cit., note 12 above, pp. 44-66; C Webster, 'Healthy or hungry thirties?', Hist. Workshop J., 1982, 13: 110-29, p. 120; M Mayhew, 'The 1930s nutrition controversy', J. Contemp. Hist., 1988, 23: 445-64; D Smith and M Nicolson, 'Nutrition, education, ignorance and income: a twentieth-century debate', in H Kamminga and A Cunningham (eds), The science and culture of nutrition, 1840-1940, Amsterdam, Rodopi, 1995, pp. 288-318; D Smith, 'The social construction of dietary standards: the British Medical AssociationMinistry of Health Advisory Committee on Nutrition report of 1934', in D Maurer and J Sobal (eds), Eating agendas: food and nutrition as social problems, New York, Aldine de Gruyter, 1995, pp. 279-303.

62 Health of the school child, 1931, London, HMSO, 1932, p. 126; PRO MH 56/53, T Carnwath to Secretary, 22/1/34; PRO MH 56/46, R H Simpson, 'Board of Education nutrition enquiry 1933-1934', 3/34, pp. 13-14.

63 PRO ED 50/204, Board of Education, 'Statistical returns relating to nutrition', 31/12/34.

64 Health of the school child, 1934, London, HMSO, 1935, p. 29. See also Harris, op. cit., note 1 above, pp. 132-6. 


\section{John Welshman}

just, to stave off deterioration in health and physique", but throughout the 1930s the Board remained concerned that Abertillery was a high spending LEA. ${ }^{65}$ Deputations from bodies such as the Standing Joint Committee of Industrial Women's Organisations visited the Board increasingly frequently, and books such as Fenner Brockway's Hungry England provided a depressing picture of conditions in Lancashire and South Wales. ${ }^{66}$ In 1933, the Save the Children Fund's report compared provision in depressed areas, enquired why rural LEAs did not provide meals, and concluded that the effectiveness of school meals justified expenditure on welfare services, while Allen Hutt's study found that evidence from SMOs in Lancashire contradicted Newman's claim that the depression had not affected children. ${ }^{67}$

Despite these studies, Newman's reports maintained that unemployment and financial retrenchment had not affected the health of schoolchildren; his report for 1932 claimed that only 1 per cent of schoolchildren were malnourished. ${ }^{68}$ Newman's annual reports to the Board and to the Ministry of Health had a valuable propaganda function in convincing people that welfare services had contained the health problems associated with the depression. In September 1933, the Daily Telegraph concluded from Newman's 1932 report to the Ministry that "in spite of the depression and the high rate of unemployment, Britain is healthier today than at any time in its history", while The Times agreed that "the population, as a whole, is now better nourished than ever before". ${ }^{69}$ Statistics including infant mortality and children's heights suggest that this was the case; the problem was that the nutritional status of a minority of the population fell well below average, and that even the average standard of nutrition left a great deal to be desired.

From 1934, the Children's Minimum Council (CMC) organized by Eleanor Rathbone and Eva Hubback put pressure on both the Ministry of Health and the Board of Education. Rathbone, author of The disinherited family (1924) and Independent MP for the Combined Universities, and Hubback, the academic and author, were also involved in the Family Endowment Society, and Marjorie Green acted as the CMC's secretary. Deputations in March 1934 and December 1935 recommended that the Ministry and Board should establish a minimum needs scale, expand the provision of meals and milk, and increase allowances for the children of the unemployed. The CMC also made perceptive criticisms of official reports and defended working-class mothers. ${ }^{70}$ In 1936, the CMC campaigned on the Special Areas Bill and the draft Unemployment Assistance Regulations, pointing out, for example, that the 26 LEAs with the highest unemployment in September 1935 provided only 2.7 per cent of children with free school meals and 12.2 per cent of children with free milk. ${ }^{71}$

65 PRO ED 50/83, J E Underwood, 'Conditions as regards physique, clothing and boots of school children in the S Wales coalfields', 21/2/30; PRO ED 123/292, C W Maudslay to J E Underwood, 16/8/32.

66 F Brockway, Hungry England, London, Gollancz, 1932.

67 Save the Children Fund, Unemployment and the child: an enquiry, London, Longmans, Green and Co, 1933, pp. 57-65, 76-7, 81, 126-7; A Hutt, The condition of the working class in England, London, Martin Lawrence, 1933, pp. 86-7.

68 Health of the school child, 1932, London, HMSO, 1933, p. 126.

69 PRO MH 139/5, cuttings from the Daily

Telegraph and The Times, 15/9/33, pp. 157-8.
70 PRO MH 55/275, 'Children's Minimum Committee: summary of proposals', 12/3/34; PRO ED 50/78, 'A children's minimum', 3/34; PRO MH 55/688, CMC, 'Evidence on malnutrition', 9/34, pp. 3-5, 9-11; PRO MH 56/249, idem, 'Statement submitted at deputation to Lord Eustace Percy', $18 / 12 / 35$, pp. 8-10, 14-15.

71 PRO MH 55/688, CMC, 'Memorandum on the Special Areas Bill', 2/36, pp. 6-7, 8-9, 11-12; PRO ED 50/214, CMC, 'Points to be put before the Parliamentary Secretary of the Board of Education, July 29th 1936'. 
In the late 1930s, the CMC continued to campaign for income scales rather than medical inspections, and an expansion of free milk. A deputation led by Eleanor Rathbone put these and other points to the President of the Board of Education in March $1939 .{ }^{72}$ Yet despite the CMC's efforts, the Board maintained that it was concerned with education rather than the relief of poverty, and that malnutrition was due to parental ignorance; on milk for example, it argued that the main problems were that parents were indifferent and children did not like its taste. In March 1939, Cecil Maudslay, Assistant Secretary at the Board's Medical Branch, wrote that "proposals which are financially impracticable and wrong in principle merely confuse the issue and hinder us in the attainment of our more limited objectives". ${ }^{73}$ Despite its campaigning, the CMC was largely unsuccessful in the interwar period and family allowances were introduced only in 1945.

One of the main demands of the CMC and other pressure groups was for the expansion of free school milk, and the main innovation by the Board in this period was the introduction of the school milk scheme in October 1934. Experiments had indicated that schoolchildren who drank milk gained height and weight more quickly, and legislation passed in 1930 gave local authorities in Scotland powers to supply milk. ${ }^{74}$ The 1921 Milk Act had set up a scheme run by the National Milk Publicity Council in which about 800,000 children received milk daily at a cost of $1 \mathrm{~d}$ for a third of a pint, and the Empire Marketing Board also attempted to stimulate the production and consumption of milk. ${ }^{75}$ In a 1934 White Paper, the Ministry of Agriculture and Fisheries argued that an expansion in milk consumption would improve public health and alleviate the problem of surplus milk, but the Treasury feared that the principle of free milk could be extended to free meals and clothes, and the Board was determined to use medical inspections rather than income scales to ensure that milk was not used to relieve poverty. ${ }^{76}$ Nevertheless, under the 1934 Milk Act, the Board of Education gave the Milk Marketing Board a subsidy of $£ 500,000$ for two years, and the milk scheme which came into operation in October made milk available to schoolchildren at a halfpenny for a third of a pint. In November 1934, the Milk Marketing Board set up an Advisory Committee on Milk Publicity chaired by Lord Astor, and Dr J Alison Glover, Edward Mellanby, and John Boyd Orr served on its scientific sub-committee; by 31 March 1936, the milk scheme included 45.8 per cent of elementary school children in England and Wales. ${ }^{77}$

Despite the progress of the milk scheme, the Board's insistence in its circular on medical selection was reminiscent of public assistance procedure and extremely unpopular. Although fewer children got school milk in rural LEAs and in the depressed

72 PRO ED 50/216, M E Green, School feeding in England and Wales, London, CMC, 1938, pp. 9-10; ibid., CMC, 'Statement on school meals and milk submitted to the President of the Board of Education', 3/39, pp. 4-10.

73 PRO ED 50/78, interview memorandum, 26/3/34; PRO ED 50/214, C W Maudslay to D H Leadbetter, 28/7/36; PRO ED 50/216, minute by C W Maudslay, 27/3/39, p. 4. See also Macnicol, op. cit., note 12 above, pp. 62-6.

74 PRO ED 50/79, cuttings from the Lancet, $28 / 1 / 28$, p. 202, and 5/1/29, p. 40; ibid., Department of Health for Scotland, Milk consumption and the growth of school children, Edinburgh, HMSO, 1930.
75 Ibid., Empire Marketing Board, 'What milk can do'; PRO ED 50/80, Earl de le Warr to M Jones, 5/2/31; Health of the school child, 1931, London, HMSO, 1932, p. 109.

76 PRO ED 50/81, Ministry of Agriculture and Fisheries, Milk policy, 22/2/34; PRO ED 24/1367, C L Stocks to E G Howarth, 1/3/34; PRO ED 50/81, C W Maudslay to G Newman, 23/7/34.

77 PP 1933-34, III, pp. 47-88; PRO MH 56/105, Lord Astor to E Hilton Young, 16/11/34; ibid., H E Magee, 'Minutes of meeting of Scientific SubCommittee, 18/12/34', 22/12/34; Health of the school child, 1935, London, HMSO, 1936, pp. 33-5. 


\section{John Welshman}

areas, the Board maintained that indifference on the part of parents and the children's dislike for milk were more significant obstacles to wider provision than poverty. ${ }^{78}$ In September 1936, the Depressed Areas Association pressed for free milk for all schoolchildren, pointing out that districts like Nantyglo and Blaina in South Wales could not increase rate expenditure, and the Board's civil servants admitted that in these areas, despite evidence of malnutrition, only a small proportion of children got milk. ${ }^{79}$ Social surveys indicated that working-class families bought the cheaper condensed milk, while the first report of the Advisory Committee on Nutrition, published in 1937, regarded milk as the single most important measure to improve health, noting that "we deplore the fact that there is a deficiency of milk in the diet of large sections of the population". ${ }^{80}$ In the late 1930s, demands for more free milk entered the rhetoric of the CMC and other pressure groups, and the milk-in-schools scheme expanded so that by 31 March 1939, 86.9 per cent of all departments in elementary schools operated it, and 55.6 per cent of children got free or subsidizied milk. While some continued to blame parents and children for not paying for milk at school, there was evidence of a change of attitude by some of the Board's civil servants. In June 1939, for example, Cecil Maudslay admitted that the amount of milk drunk at school was never likely to reach the one to two pints a day recommended by the Advisory Committee, and poor families drank little milk because it was expensive. ${ }^{81}$

\section{Fighting for Credibility, 1935-39}

Although the introduction of the milk scheme provided valuable propaganda for the Board, social surveys of Brynmawr, Southampton, Merseyside, and London published in 1934 found a high incidence of child poverty, revealed contradictions in the nutrition statistics, and maintained that low wages and poor housing were more significant than inefficiency among working-class mothers. ${ }^{82}$ As the conditions in the depressed areas worsened there were more deputations, and the appearance of studies such as McNally's Public ill health, published by Victor Gollancz for the Left Book Club, indicated that the nutrition question had become

78 PRO ED 50/81, Board of Education, circular 1437, Provision of milk for school children, 5/9/34; PRO ED 24/1367, H Ramsbotham to Education, 3/12/34, pp. 2-3; ibid., W G Wilkins to J H Thomas, 5/12/34; PRO ED 50/223, C W Maudslay to D E Vandepear, 14/7/36; Health of the school child, 1935, London, HMSO, 1936, p. 35.

79 PRO ED 50/223, interview memorandum, 8/9/36; ibid., E N Strong to C W Maudslay, 25/9/36.

80 C E McNally, Public ill health, London, Gollancz, 1935, p. 199; PRO MH 56/259, Ministry of Health, Advisory Committee on Nutrition: first report, London, HMSO, 1937, pp. 29-30.

81 Health of the school child, 1938, London, HMSO, 1940, p. 23; PRO ED 50/204, C W Maudslay to Secretary, $29 / 6 / 39$ and $13 / 7 / 39$. See also Macnicol, op. cit., note 12 above, pp. 65-6; C Webster, 'The health of the school child during the depression' in N Parry and D McNair (eds), The fitness of the nation-physical and health education in the nineteenth and twentieth centuries, Leicester, The History of Education Society of Great Britain, 1983, pp. 70-85, p. 77; J S Hurt, 'Feeding the hungry schoolchild in the first half of the twentieth century', in D J Oddy and D S Miller (eds), Diet and health in modern Britain, London, Croom Helm, 1985, pp. 178-206; D Dwork, 'The milk option. An aspect of the history of the infant welfare movement in England, 1898-1908', Med. Hist., 1987, 31: 51-69; Harris, op. cit., note 1 above, pp. 124-5.

82 P Ford, Work and wealth in a modern port: an economic survey of Southampton, London, George Allen and Unwin, 1934, p. 120; D Caradog-Jones, Social survey of Merseyside, London, Hodder \& Stoughton, 1934, vol. 3, p. 39; H Llewellyn-Smith, The new survey of London life and labour, London, P S King \& Son, 1934, vol. 6, pp. 304, 307, 314-15, 326-9; H Jennings, Brynmawr: a study of a distressed area, London, Allenson \& Co, 1934, pp. 156-7. 


\section{School Meals and Milk in England and Wales, 1906-45}

much more political. ${ }^{83}$ The Board became more defensive, and while it still told deputations that the School Medical Service had contained the effects of the depression on the health of schoolchildren, these claims sounded increasingly hollow. Newman retired as CMO in 1935 and the first annual report of his successor, Sir Arthur MacNalty, summarized the memorandum of December 1934; it eliminated the term "malnutrition", recommended clinical examinations, and changed the categories from "excellent" to "normal" and "subnormal" to "slightly subnormal". Yet the methods were essentially unchanged and did not eliminate unlikely regional variations; MacNalty conceded that its flaws were "inherent and unavoidable in any clinical method, for the four categories have no defined limits and one must merge into another by gradual transition". The report also indicated that dining rooms were often dark, poorly ventilated and had no toilets or cloakrooms, meals were monotonous, and there was often prejudice against children receiving free milk. MacNalty recommended cookery classes but admitted that "poverty and the lack of proper implements prevent many girls from attempting to apply in their homes the lessons which they are given at school". 84

Despite the attempt to reform the methods of assessing nutrition, 1935 can be seen as a turning point after which the Board's credibility crumbled and it increasingly avoided the issue of nutrition. The survey published in 1936 by Dr G C M M'Gonigle and J Kirby pointed out the paradox that many more children were fed than were found suffering from malnutrition at medical inspections, and they argued that poverty was the primary cause of malnutrition. They dismissed the inefficiency argument, saying of working-class mothers that "it is doubtful if education in the principles of nutrition would enable them to materially improve the nutritional condition of their families". They concluded from a survey of the incomes and budgets of 126 families in Stockton-on-Tees that half the population of England and Wales was below a nutrition safety line. ${ }^{85}$ Although Boyd Orr's study may have lacked the passion of M'Gonigle and Kirby's book, his comparison of the diets of six income groups and optimum food requirements was more scientific and its conclusions more difficult to avoid. He found that the consumption of milk, eggs, fruit, vegetables, meat and fish rose with income, while rickets, bad teeth, anaemia and stunted growth were widespread in the lower income groups. Boyd Orr concluded that the diet of his poorest group (4.5 million) was deficient in every constituent; the diet of the second group ( 9 million) was adequate in protein, fat, and carbohydrate but deficient in vitamins and minerals, and the diet of the third group ( 9 million) was deficient in several vitamins and minerals. He recommended that the poorer groups should increase their consumption of milk, eggs, butter, fruit, vegetables and meat by 12 to 25 per cent. ${ }^{86}$ When the Ministry of Health's Advisory Committee claimed that Boyd Orr's conclusions were "somewhat tentative", he was forced to publish the book under his own name because of Government pressure, and he and M'Gonigle were told that their names would be removed from the Medical Register if they proceeded with a BBC broadcast. ${ }^{87}$

83 PRO ED 50/50, C W Maudslay to W P Wheldon, 5/4/35; McNally, op. cit., note 80 above, passim.

84 Health of the school child, 1935, London, HMSO, 1936, pp. 11-13, 17-20, 27, 39-42.

85 G C M M'Gonigle and J Kirby, Poverty and public health, London, Gollancz, 1936, pp. 54, 106-7, 256-7, 263.

$86 \mathrm{~J}$ Boyd Orr, Food health and income: report on a survey of adequacy of diet in relation to income, London, Macmillan, 1936, pp. 42-3, 49-50.
87 PRO MH 56/251, Ministry of Health, 'Report by the Advisory Committee on Nutrition on "Food health and income" by Sir John Boyd Orr', 11/36, pp. 1-3; J Boyd Orr, As I recall, London, MacGibbon and Kee, 1966, pp. 115-17. See also $D$ Smith and $M$ Nicolson, 'Health and ignorancepast and present', in S Platt, et al. (eds), Locating health: sociological and historical explorations, Aldershot, Avebury, 1993, p. 223. 
In 1936-7, the Board also came under increasing pressure because of conditions in the depressed areas. Wal Hannington's study was critical of the provision of meals, argued that the promotion of physical education was premature, given the persistence of malnutrition, and recommended free school meals for all children with unemployed parents. ${ }^{88}$ Hannington, President of the National Unemployed Workers Movement, was regarded as politically motivated, but his arguments were supported by the Board's own unpublished surveys. In October 1936, a survey by the Board's inspectors in South Wales found that of the children classed as " $C$ " and " $D$ " at medical inspections, 34.78 per cent in Senghenydd and Bargoed, 43.35 per cent in Nantyglo, 41.02 per cent in the Rhondda, and 37.61 per cent in Mountain Ash were not receiving either school meals or milk. The report judged that "we cannot escape the conclusion that the prolonged and severe unemployment in these districts is reflected in some lowering of the standard of health" ${ }^{89}$ The Board accepted that these LEAs could not improve income scales without additional grants, or afford more medical staff to conduct more frequent nutrition surveys, but deputations arguing for more meals and milk faced a familiar litany of excuses. ${ }^{90}$

In March 1937, Maudslay reassured the Treasury that the Board was fully aware of the deficiencies of the School Medical Service in the new Special Areas, and argued that increases in block grants had improved the financial position of LEAs. ${ }^{91}$ Yet reports on the North West of England found that while conditions were better than in South Wales, there was a "lowered physical standard" among schoolchildren and adolescents, and the Ministry of Health's Parliamentary Secretary, Sir Edward Campbell, Conservative MP for Bromley, noted that the condition of schoolchildren "left much to be desired". 92 Maudslay maintained that schoolchildren's health was better than expected, and malnutrition was not always due to poverty, but Pearse, who summarized the reports, wrote that the only remedies for the problems of the depressed areas were the abolition of poverty and higher wages. ${ }^{93}$ Further surveys of Cumberland in May 1938 found "considerable evidence of subnormal nutrition", and in March 1939 the author concluded that unemployment had affected health. ${ }^{94}$ The Board's Senior MO, Dr Alison Glover, who worked on some of the earlier reports, agreed with these findings, and at the Ministry, Campbell commented that the report was a "shocking commentary on our social "system". 95

\footnotetext{
$88 \mathrm{~W}$ Hannington, The problem of the distressed areas, London, Gollancz, 1937, pp. 61, 79-82, 91, 283.

89 PRO MH 55/629, J Pearse, T W Wade, J V

Evans, and $\mathrm{J} E$ Underwood, 'Inquiry into the present conditions as regards the effects of continued unemployment on health in certain areas of South Wales and Monmouth', 23/10/36, pp. 18, 21, 26, 29, 61. See Webster, op. cit., note 32 above, pp. 216-18.

90 Ibid., C W Maudslay, comments on the report, 5/11/36; PRO MH 56/213, 'Deputation from national women's organisations', 22/10/36; PRO ED 50/175, NUT, 'The depressed areas', 11/2/37, p. 4.

91 PRO MH 61/11, C W Maudslay to F N Tribe, 23/3/37.

92 PRO MH 61/6, J Pearse, 'Investigation of Special Areas: summary of reports on West
}

Cumberland', 20/8/37; ibid., E Campbell to H A de Montmorency, 19/11/37.

${ }^{93}$ PRO ED 50/204, minute from C W Maudslay, 31/12/37, pp. 2-3; PRO MH 61/7, J Pearse,

'Memorandum on possible remedial measures affecting the unsatisfactory findings detailed in the report submitted on the Special Areas', 20/3/38, pp. 1,7 .

94 PRO ED 50/204, J Pearse, 'Investigation of Special Areas: West Cumberland I', 11/5/38, p. 28; PRO MH 61/7, idem, 'Report on inquiries conducted in the Special Areas as to the effect of unemployment on health', 27/3/39, p. 79.

95 PRO MH 61/7, J A Glover to T Carnwath, 15/4/39; ibid., E Campbell to E D Macgregor, $21 / 3 / 39$. 
In this period the Board used its promotion of physical education as a smokescreen for its failings on school meals, and when nutrition was mentioned, as in the keep fit campaign in the autumn of 1937, it was cookery lessons that were highlighted. Individual SMOs were now more critical of the assessment of nutrition, and they were encouraged by independent bodies such as Political and Economic Planning (PEP). In January 1937, Planning, its fortnightly broadsheet, argued that from 1908 to 1934, when there was revolutionary scientific research on nutrition, the Board had published annually "a series of valueless statistics", and it urged the Board to decide if malnutrition could be measured. ${ }^{96}$ These criticisms were carried further in PEP's Report on the British Health Services, which argued that the SMOs' clinical assessment of nutrition was not objective since their standard was the average for their area, the idea of "normal" was misleading, and they needed to have a complete clinical history and know more about home conditions. The PEP report concluded of the nutrition statistics that "the assumptions on which their measurements are based are not very reliable and the standards adopted not high", and it agreed with Boyd Orr that a large group made up of the unemployed and large families was below an income level required for an adequate diet, and that a larger group of low wage-earners also suffered from malnutrition. It suggested that poverty, bad housing and ignorance hindered food preparation, but argued that the most effective way of improving nutrition was through higher wages and better housing. The PEP report recommended that people should be encouraged to drink more milk, and it concluded that "the development of nutrition policy ought to take precedence over all other claims for the expansion of health services". 97

Although the Ministry of Health had continued to experiment with alternative methods of assessing nutrition, the Advisory Committee had concluded that no known method was reliable, and a paper read to the Royal Statistical Society in November 1937 by Robin Huws Jones, a Liverpool University statistician, further undermined the Board. ${ }^{98}$ In the period January 1935 to October 1936, children in 27 schools in Liverpool had been examined by the same doctor and classified using the Board's categories, but when the children were re-examined later by four experienced doctors, the results varied greatly. This was confirmed by similar experiments in other rural and urban areas. Huws Jones found that assessments of malnutrition varied according to the doctor doing the examination, and that doctors disagreed both with each other and with their own assessments of the same population at different times. He concluded that the Board's methods of assessing nutrition were "unreliable", the results "of doubtful value" and the conclusions "insecurely founded". 99 The British Medical Journal agreed that the Board had placed too much emphasis on its statistical tables and that medical inspections could not produce comparable regional figures on nutrition. While the Lancet defended SMOs,

96 PRO MH 56/213, PEP, Planning, vol. 88, $12 / 1 / 37$, p. 14. On the links between PE and nutrition see J Welshman, 'Physical education and the school medical service in England and Wales, 1907-1939', Soc. Hist. Med., 1996, 9(1): 31-48.

97 Political and Economic Planning [PEP], Report on the British health services: a survey of the existing health services in Great Britain with proposals for future development, London, PEP,
1937, pp. 319-37; S M Herbert, Britain's health, Harmondsworth, Penguin, 1939, pp. 174-7.

98 PRO ED 50/204, Board of Education, 'The improvement of nutrition', 30/12/35, p. 14; PRO MH $56 / 259$, Ministry of Health, Advisory Committee on Nutrition: first report, London, HMSO, 1937, p. 26.

99 R Huws Jones, 'Physical indices and clinical assessments of the nutrition of schoolchildren', J. $R$. Statist. Soc., 1938, 101: 1-52, pp. 3-6, 32-3, 50-2. 
it accepted the criticisms made by Huws Jones. ${ }^{100}$ By September 1938, when the CMO's annual report for 1937 was published, the Board had had more time to reflect on Huws Jones's paper and it now accepted that there was no objective method of assessing nutrition, clinical assessment lacked scientific accuracy, and SMOs needed records of heights and weights. ${ }^{101}$ Nevertheless, the Board's immediate reaction was more revealing. Its observer at Huw Jones's paper noted that "there is no method for the accurate assessment of nutrition", and while Maudslay claimed that the Board's method was the most reliable devised, he admitted that if discrepancies between SMOs were publicized, it would confirm that "our method is of little value". 102

The final year of peace illustrated that school meals continued to be characterized by a complex mix of progress and patchwork. By 1938-39, 273 LEAs were providing free meals under Sections 82-84 of the 1921 Education Act, 687,855 children were fed free at some time in the year, and over 26 million meals and 114 million milk meals were served. Nevertheless, these aggregate figures disguised the fact that under the 1921 Act low percentages of children received free meals and milk; only 11.2 per cent of schoolchildren got free milk, 1.2 per cent got free meals, and 2.8 per cent got free meals and milk. ${ }^{103}$ Some observers continued to blame malnutrition on the inefficiency of working-class mothers, and others remained complacent. ${ }^{104}$ At the same time, many of the SMOs whose medical inspections provided the statistical basis for the Board of Education's statements on nutrition were increasingly sceptical of the Board's pronouncements, as were nutrition experts and others interested in public health, while social surveys pointed out that poverty had a serious impact on the working-class diet, and low rates hindered services in depressed areas. ${ }^{105}$

The Committee Against Malnutrition, whose members included Frederick Le Gros Clark, Gowland Hopkins, Boyd Orr, and M'Gonigle, began to formulate a national food policy, and other individuals were critical of the Board. ${ }^{106}$ Frederick Le Gros Clark argued that the nutrition statistics were "well-nigh worthless", one in five children had a very inadequate diet and two in five were below the optimum, and the country had drifted into "complacency and self-delusion". ${ }^{107}$ Richard Titmuss stated that there were no reliable standards for assessing nutrition or subnormal health, and "normality" and "average" were often confused. He explained why the statistics were misleading, pointed out that many working-class children consumed less than the pint of milk a day recommended by the Advisory Committee on Nutrition, and concluded that the main cause of poor nutrition

100 Br. med. J., 1937, i: 1175; Lancet, 1937, ii: 1257-8.

101 Health of the school child, 1937, London, HMSO, 1938, pp. 19, 21.

102 PRO ED 50/204, notes on Huws Jones's paper, $16 / 11 / 37$, pp. 2-3, 9; ibid., minute from C W Maudslay, 1/12/37. See also Harris, op. cit., note 1 above, pp. 132-6.

103 Health of the school child, 1938, London, HMSO, 1940, pp. 21-2.

104 F Le Gros Clark, National fitness: a brief essay on contemporary Britain, London, Macmillan, 1938, pp. ix-x; W Crawford and H Broadley, The people's food, London, Heinemann, 1938, pp. 303-5;

\author{
G Newman, The building of a nation's health, \\ London, Macmillan, 1939. \\ 105 The Pilgrim Trust, Men without work: a report \\ made to the Pilgrim Trust, Cambridge University \\ Press, 1938, p. 126; E Wilkinson, The town that was \\ murdered: the life-story of Jarrow, London, \\ Gollancz, 1939, pp. 250-3; M Spring Rice, Working- \\ class wives: their health and conditions, London, \\ Penguin, 1939, Virago edn, 1981, pp. 153, 156. \\ 106 PRO MH 56/213, Committee Against \\ Malnutrition, 'Towards a national food policy', $6 / 38$. \\ 107 Clark, op. cit., note 104 above, pp. 4-5, 86, \\ $107-8,136,213$.
}


was poverty which "precludes the purchase of a diet sufficient and properly balanced to promote growth and to maintain health". 108 There was evidence that the Board was changing its stance. In November 1938, Cecil Maudslay noted that malnourished children in LEAs such as Abertillery got no meals or milk because no nutrition surveys were held and because the standards of the SMO were "unduly optimistic", while Earl de la Warr admitted that in many LEAs provision was inadequate and concluded that "we have still a long way to go before we have fully achieved our end". 109

\section{The Second World War}

The evacuation of schoolchildren in September 1939 produced rather contradictory evidence on the nutritional state of city children and the effects of rural life, but in the early 1940s the Board of Education came fully to accept criticism of its outdated methods and to provide school meals and milk on a more generous level. Initially, householders were to pay a charge for communal meals for evacuees, and the Board advised that local authorities should use voluntary organizations such as the Women's Voluntary Service to keep overheads down. ${ }^{110}$ A Ministry of Health circular issued in August attempted to increase milk consumption among expectant and nursing mothers and children under school age, but for schoolchildren the feeding centres were closed in evacuation and neutral areas, families did not want to pay for meals out of the billeting allowance, reception areas made little effort, and by October 1939 the provision of school meals had declined to a low level. ${ }^{111}$ In November 1939, a Board circular encouraged local authorities to co-operate with billeting authorities and voluntary organizations to hire premises for communal feeding and provide meals; the Board would pay for some of the expenditure and proposals would be processed quickly. Moreover the Ministry of Health now admitted that despite the report of the Advisory Committee on Nutrition, workingclass families consumed small quantities of milk, and that "the provision for necessitous under-nourished children is at present incomplete". 112 In January 1940, the Milk Marketing Board argued that children under five, schoolchildren, and nursing and expectant mothers should drink more milk, and while it wished to retain income tests, it argued that "necessitous" children should get more free milk. ${ }^{113}$

Pressure groups continued to argue for increased provision of free milk, and in the new climate their demands were more likely to be met; a letter from the MRC, for example, commented in March 1940 of Cathcart and the "Glasgow school" that "they seem to have got into a groove in Glasgow and to have gone on quite regardless of all the work which has been done around them in the last fifteen years". ${ }^{114}$ Many of the Board's critics

108 R M Titmuss, Poverty and population: a factual study of contemporary social waste, London, Macmillan, 1938, pp. 96-7, 100-1, 108-9, 235, 246-7, 249.

109 PRO ED 123/292, C W Maudslay to J E Underwood, 4/11/38; Med. Offr, 1938, 47: 228. See also Webster, op. cit., note 32 above, p. 214, and Harris, op. cit., note 1 above, pp. 156-8.

110 PRO ED 10/245, S Laskey to A L Binns, 28/7/39.

111 PRO MH 55/647, Ministry of Health, Circular

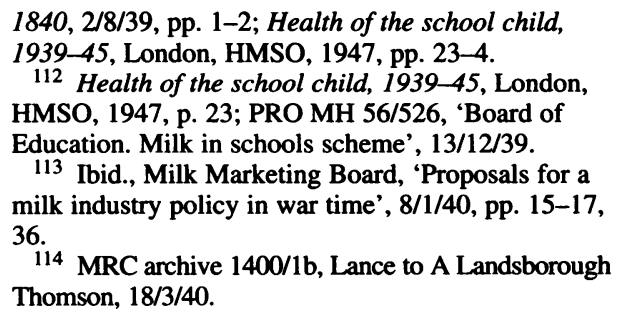




\section{John Welshman}

continued to grumble about the assessment of malnutrition and provision of meals and milk. Edgar Wilkins, SMO for Birmingham, argued that income scales for free school meals were too low, and the failure to define malnutrition and the vague terminology were "evidence of the uninformed state of the whole subject". A social survey of Tyneside noted that poorer local authorities like Jarrow and Hebburn provided better social services than Newcastle, and concluded of the assessment of nutrition that "the whole matter is obviously in a state of chaos". ${ }^{115}$ Surveys increasingly reflected new standards of decency and citizenship. The National Union of Teachers wrote that children should brush their hair and wash their hands before meals and eat slowly, while a survey of school canteens in Hertfordshire quoted the opinions of children invited to write essays on school meals. The survey suggested that children should grow fruit and vegetables in school gardens, set the tables and decorate them with flowers, and strike up friendships with kitchen staff; it concluded that "it is our business to transform the canteen from an improvised method of getting the children fed into a part of the formative influence of their training". 116 Discrimination was increasingly unacceptable; L Haden-Guest, Labour MP for North Islington, wrote that all children should get free meals and milk, noting that "to attempt to discriminate between necessitous and non-necessitous children is socially and psychologically disastrous in school life". ${ }^{117}$ The Women's Group on Public Welfare's report on evacuation was permeated by an emphasis on the "social problem group", but suggested that the wartime rationing system could improve peacetime diets, meals should be provided in all elementary and secondary schools, and SMOs should have optimum rather than minimum standards. ${ }^{118}$

The difference between the 1930s and the 1940s was that in the latter, the Board of Education increasingly accepted criticism of its methods of assessing nutrition, and of the provision of school meals and milk. Within the Board, progressive views appeared to have triumphed over conservative opinion. In February 1940, Dr Alison Glover wrote that the nutrition figures were overly optimistic, and while he was not surprised at differences between the figures of SMOs and the Board's MOs, he was disappointed that SMOs visited by the Board continued to produce "improbable figures". He estimated that of the figures for 1938 and 1939, half were possible, a quarter had at least one serious mistake, and a quarter were unacceptable or used methods of classification different to those advocated by the Board. Glover concluded that "it cannot be denied that a very large proportion of the returns are so unreliable as to be valueless for any purpose", and when Maudslay argued that visits by MOs would help to reduce the number of unlikely figures, Glover wrote in the margins "hope springs eternal". ${ }^{119}$ By February 1941, a colleague

115 E H Wilkins, 'The environmental background of the school child', Med. Offr, 1941, 65: 145-7, p. 145; idem, 'The future of the School Medical Service: some suggested reforms', Med. Offr, 1941, 66: 109-12, p. 111; D M Goodfellow, Tyneside: the social facts, Newcastle Co-Operative Society, 1940, 2nd edn, 1942, pp. 52-8.

116 National Union of Teachers, School canteen handbook, Gloucester, NUT, 1940, p. 9; F Le Gros Clark, The school child and the school canteen, Hertford, Hertfordshire County Council, 1942, pp. 21-35.

\footnotetext{
117 R Padley and M Cole (eds), Evacuation survey: a report to the Fabian Society, London, Routledge, 1940, pp. 182-3.

118 Women's Group on Public Welfare, Our towns: a close-up, Oxford University Press, 1943, pp. 45-6.

119 PRO ED 50/204, J A Glover, 'Statistical returns of assessment of nutrition at routine school medical inspections. A critical examination', 2/40, pp. 16, 21-3.
} 
agreed that "the figures themselves are so obviously inconsistent and unreliable that I think it is not merely misleading but unwise to publish them, since they could be readily attacked". ${ }^{120}$ Perhaps most revealingly, even Newman admitted in 1941 that the lack of a reliable index of malnutrition, the desire to distinguish school meals from Poor relief, and the emphasis on milk rather than meals, had all created complacency in the interwar period. $^{121}$

These admissions were accompanied by an expansion of school meals and milk. In June 1940, Herwald Ramsbotham, Conservative MP for Lancaster and the Board's Parliamentary Secretary, wrote that if meals could be established and made popular, "it would be an important educational advance", and in the Food Policy Committee of the War Cabinet, Clement Attlee noted that discrimination caused friction, was expensive, and was reminiscent of charity. ${ }^{122}$ The Ministry of Health's circular of June 1940 introduced a national scheme of free or cheap milk for expectant and nursing mothers and children under five; milk cost $2 \mathrm{~d}$ a pint or was free if the parents' income fell below 40 s a week, and the whole cost was borne by the Exchequer. ${ }^{123}$ Some of the Board's civil servants now admitted that poverty was associated with low wages and large families, and a new circular issued in July 1940 increased the grants towards school meals. ${ }^{124}$ The Board abolished the distinction between feeding centres and school canteens in December 1940, the provision of meals and milk expanded following the June circular, and by January 1941, the Board had approved 40 proposals for new school canteens, and were considering plans for a further $60 .^{125}$ The Ministry of Food established a communal meals division and increasingly school meals were viewed as part of an integrated policy on nutrition that also embraced British Restaurants and factory canteens; by July 1941, Board of Education officials were beginning to envisage universal school meals as a permanent feature of the education system. In October 1941, the Government increased grants to between 70 and 95 per cent of local authority costs and abandoned proof of "necessitousness" and malnutrition, and in May 1943 new 100 per cent equipment grants helped them to build more school canteens. Under the 1944 Education Act, local authorities had a duty to provide school meals and milk, and to employ a qualified and experienced school meals organizer, and by October 1945, nearly two million children in primary and grant-aided secondary schools were getting school dinners (39.7 per cent) and over three million ( 71.7 per cent) were getting milk. ${ }^{126}$ While the later 1940 s also saw the creation of the stereotype of the "problem family", the War had seen a transformation of attitudes towards school meals and milk, and a new acceptance by the Board of Education

120 Ibid., E D Marris's comments on J A Glover's report, $12 / 2 / 41$.

121 G Newman, English social services, London, William Collins, 1941, p. 32.

122 PRO ED 50/215, H Ramsbotham to C Attlee, 8/6/40; ibid., C Attlee, 'The provision of cheap food for the poorer classes'.

123 PRO MH 56/527, Ministry of Health, circular 2053, Supply of milk to mothers and children, $19 / 6 / 40$.

124 PRO ED 50/215, F Hemming, 'The feeding of children in war time', 19/6/40; Health of the school child, 1939-45, London, HMSO, 1947, p. 24.

125 PRO ED 50/204, C W Maudslay's comments on J A Glover's report, 16/10/40; PRO ED 50/215, N D Bosworth Smith to Secretary, 23/1/41.

126 Health of the school child, 1939-45, London, HMSO, 1947, p. 29. See also R M Titmuss, Problems of social policy, London, HMSO, 1950, pp. 149, 509-14; Hurt, op. cit., note 80 above, pp. 198-201; J Ivatts, 'The school meals service', Soc. Policy Adm., 1992, 26(3): 226-44; J Burnett, 'The rise and decline of school meals in Britain, 1860-1990', in J Burnett and D Oddy (eds), The origins and development of food policies in Europe, Leicester University Press, 1994, pp. 55-69; Harris, op. cit., note 1 above, pp. 155-60, 195-200. 


\section{John Welshman}

of the inadequacies of welfare services. A consensus on school meals and milk had been established that was to survive until the late 1960s.

\section{Conclusions}

In enabling LEAs to provide meals, and marking significant changes in attitudes to state and family responsibilities, the 1906 Education (Provision of Meals) Act was an important step forward, and it was consolidated by legislation in 1914, 1921 and 1934. By September 1939, the number of LEAs providing meals and milk, and the number of meals served, had increased greatly, and many schoolchildren were receiving free or subsidized milk under the milk-in-schools scheme. Yet the interwar period was one of steady but slow progress, and small percentages of children received free school meals. The Board of Education interpreted legislation narrowly, refused to accept any wider responsibility for child poverty, and rarely put pressure on LEAs which provided inadequate meals services. Although the methods used by SMOs to measure the nutritional state of schoolchildren at medical inspections were fundamentally flawed, the system proved remarkably resilient, and the Board's "reforms" of 1935 were little more than a restatement of the original principles. Particularly in the depressed areas of the North East of England and South Wales, the problem of low rates meant that the provision of school meals and milk remained inadequate, but while Government departments were complacent, they also mounted a surprisingly successful defence against deputations and pressure groups. Innovations, such as the school milk scheme of 1934, aimed more to solve the problems of the dairy industry than to improve the health of schoolchildren. Some developments in nutritional science, such as scientific research into vitamins, increasingly served to undermine the Board's methods of assessing nutrition. On the other hand, an intellectual climate that was receptive to the emphasis of the "Glasgow school" on parental efficiency shifted only in the late 1930s from the eugenicist emphasis on the individual towards the greater emphasis on the environment and the humanitarism that was to characterize the early 1940s. It is important not to exaggerate the extent of the wartime changes. By 1939 , the milk-in-schools scheme had already reached a high proportion of schoolchildren. Groups and individuals such as the CMC, PEP and Richard Titmuss were beginning to anticipate universal health services and the breakdown of the old central-local relationship, and opinion within the Board of Education had undergone a sea-change. But it was only in the early 1940 s that radical opinion entered mainstream political debate, the eugenicist emphasis on parental inefficiency evaporated, and in the context of a heightened awareness of the importance of nutrition in wartime, school meals and milk were dramatically expanded.

Although recent work has produced a more subtle appreciation of the multiplicity of factors affecting organizations like the School Medical Service, much of it has centred on central policy-making and, apart from some work on South Wales and the North East of England, has ignored the local dimension. This is a particularly serious omission given the permissive nature of legislation and the degree to which provision varied between local authorities. Little is known about the links between the work of the School Medical Service and other local authority public health services, the way services were funded through rates or Exchequer grants, and the effect of welfare services on the health of local 
schoolchildren. Much work remains to be done on the local social, economic, and political context of health provision in individual boroughs, county boroughs, counties, and in the smaller urban districts; although places like Merthyr Tydfil and Jarrow have received some attention, much less is known about cities such as Leicester or similarly anonymous rural areas. Moreover while M'Gonigle's role is now acknowledged, the training, status and influence of most SMOs, and the nature of their relationship with elected councillors and aldermen on Education Special Services sub-committees have still to be explored. It is through intensive local studies of individual local authorities, employing SMO reports, committee minutes, provincial newspapers, and other local records that some of these questions may be resolved. Historians have provided increasingly sophisticated accounts of public health in twentieth-century Britain, including a new full-length study of the School Medical Service, but it is now time for them to turn from central to local policymaking, and to move from the offices of Whitehall to schools, streets, and houses at the local level. 